\title{
Ketenagakerjaan Dalam Perspektif Omnibus Law
}

\author{
Anggreany Haryani Putri \\ Fakultas Hukum, Universitas Bhayangkara Jakarta Raya \\ Email: anggreany.haryani@dsn.ubharajaya.ac.id
}

Article info

Received: Ags 20,2021 Revised: Sep 14, 2021 Accepted: Oct 12, $2021 \quad$ Published: Dec 9, 2021

DOI: https://doi.org/10.31599/krtha.v15i2.721

Keywords : Omnibus Law, Employment Creation, Economic Growth

Abstract : Omnibus Law is a new legal product designed as a form of breakthrough to replace existing regulations or laws. This is inseparable from the advantages possessed by the omnibus law itself. As a regulation that contains more than one regulatory content, Omnibus Law is able to overcome overlapping regulations. the application of the Omnibus law can simplify regulations by revoking or amending a number of laws that have been in effect previously. In the Job Creation Bill, employment is one of the clusters discussed, Apart from the lack of compliance with the current situation and developments in the Manpower Act, Indonesia is also still faced with other problems in the form of a less conducive labor climate, investment and business climate and not yet optimal creation. employment in the country. Through the Omnibus Law, the government will make improvements to the substance of Law no. 13 of 2003 concerning Labor that is more equitable and supports the investment climate by continuing to improve the protection and welfare of workers by regulating the fulfillment of the constitutional rights of article 27 paragraph 2 of the 1945 Constitution of the Republic of Indonesia by regulating Foreign Workers, Outsourcing, Termination of Employment, Working Hours, and minimum wages.

Kata kunci : Omnibus Law, Cipta Lapangan Kerja, Pertumbuhan Ekonomi

Abstrak : Omnibus Law merupakan produk hukum baru yang di rancang sebagai bentuk trobosan untuk menggantikan peraturan peraturan atau undang undang yang ada sebelumnya. hal ini tak terlepas dari kelebihan yang dimiliki oleh omnibus law itu sendiri. Sebagai suatu peraturan yang mengandung lebih dari satu muatan peraturan, Omnibus Law mampu dalam mengatasi tumpang tindihnya regulasi. penerapan Omnibus law dapat menyederhanakan peraturan dengan cara mencabut atau mengubah sejumlah Undang-Undang yang telah berlaku sebelumnya. Dalam Undang - Undang No. 11 Tahun 2020 Tentang Cipta Kerja, ketenagakerjaan menjadi salah satu klaster yang dibahas, Selain karena masih kurang sesuainya Undang Undang ketenagakerjaan dengan situasi dan perkembangan saat ini, Indonesia juga masih dihadapi dengan masalah lain berupa kurang kondusifnya iklim ketenagakerjaan, investasi dan iklim usaha serta belum optimalnya penciptaan lapangan kerja di tanah air. Melalui Omnibus Law, pemerintah akan melakukan penyempurnaan substansi UU No. 13 Tahun 2003 tentang Ketenagakerjaan yang lebih adil dan mendukung iklim investasi dengan tetap meningkatkan perlindungan dan kesejahteraan pekerja dengan mengatur pemenuhan hak konstitusi pasal 27 ayat 2 UUD Negara Republik Indonesia Tahun 1945 dengan mengatur Tenaga Kerja Asing, Outsourcing, Pemutusan Hubungan Kerja, jam kerja, dan upah minimum. 


\section{PENDAHULUAN}

Perdebatan mengenai Omnibus Law sebagai sarana utama untuk penataan regulasi, meramaikan masyarakat di Indonesia, ketika metode Omnibus Law yang sebelumnya tidak banyak dikenal di Indonesia negara dengan sistem hukum Eropa Kontinental, menjadi digunakan dalam penyusunan Undang - Undang No. 11 Tahun 2020 Tentang Cipta Kerja yang menjadi Program Legislasi Nasional Prioritas Tahun 2020. Kebijakan reformasi regulasi melalui implementasi Omnibus Law di Indonesia. ${ }^{1}$

Penerbitan Undang - Undang No. 11 Tahun 2020 Tentang Cipta Kerja sebagai suatu kebijakan hukum (legal policy) menjadi perhatian publik, karena omnibus law belum dikenal dalam sistem hukum Indonesia, ada resentralisasi kewenangan di pemerintah pusat, berpengaruh pada hak tenaga kerja, serta keberpihakan pada investor. Salah satu penyebab keengganan investor untuk berinvestasi di Indonesia adalah sulitnya berusaha di Indonesia, sulitnya berinvestasi di Indonesia berimplikasi pada rendahnya daya saing Indonesia dibandingkan negara tetangga, Upaya yang dilakukan oleh pemerintah untuk meningkatkan kemudahan berusaha di Indonesia adalah mengeluarkan Peraturan Presiden Nomor 91 Tahun 2017 tentang Percepatan Pelaksanaan Berusaha. implikasi dalam hal perizinan berusaha merupakan hal yang menjadi substansi utama. Nomenklatur Undang - Undang No. 11 Tahun 2020 Tentang Cipta Kerja.

Lahirnya Undang - Undang No. 11 Tahun 2020 Tentang Cipta Kerja dijadikan sebuah skema membangun perekonomian agar mampu menarik investor untuk menanamkan modalnya di Indonesia, diharapkan mampu menciptakan hukum yang fleksibel, sederhana, kompetitif, dan responsif demi terwujudnya keadilan sosial bagi seluruh rakyat Indonesia sebagaimana amanat Konstitusi, ${ }^{2}$ serta mengembangkan sistem hukum yang kondusif dengan menyinkronkan undang-undang melalui satu undangundang saja dengan konsep omnibus law Pemerintah memandang perlu adanya UndangUndang No. 11 Tahun 2020 Tentang Cipta Kerja ini karena tingginya angka pengangguran di Indonesia.

Metode Omnibus Law mampu melakukan perubahan, pencabutan, atau pemberlakukan beberapa karakteristik dari sejumlah fakta yang terkait tapi terpisahkan oleh peraturan perundang-undangan dalam berbagai lingkup yang diaturnya. Keberadaan

1 Tarsan Umarama. (2021). Constitutional Question di Mahkamah Konstitusi Sebagai Pelindung Hak Konstitusional Warga Negara Perspektif Siyasah Qadlaiyyah. KRTHA BHAYANGKARA, 15(1). https://doi.org/10.31599/krtha.v15i1.511

2 Asshiddiqie, J., \& Marwan, A. . (2020). Proklamasi Menurut Mohammad Yamin: Berdaulat Dan Berkonstitusi. Jurnal Hukum Sasana, 5(1). https://doi.org/10.31599/sasana.v5i1.89 
Undang - Undang No. 11 Tahun 2020 Tentang Cipta Kerja didesain sebagai Omnibus Law yang dapat menyeimbangkan antara ketiga tipe umum regulasi yaitu: pertama, economic regulation, dimaksudkan untuk memastikan efisiensi pasar, sebagian melalui promosi daya saing yang memadai di antara para pelaku usaha. Kedua, social regulation, dimaksudkan untuk mempromosikan internalisasi semua biaya yang relevan oleh aktor. Ketiga, administrative regulation, yang bertujuan untuk memastikan berfungsinya operasi sektor publik dan swasta.

Undang-Undang No. 11 Tahun 2020 Tentang Cipta Kerja memiliki beberapa klaster yang salah satu diantaranya mengatur tentang ketenagakerjaan. Pada klaster ketenagakerjaan Pemerintah berupaya untuk mengharmonisasikan undang-undang tersebut agar sejalan sehingga mampu memberikan sebuah ruang kepada investor untuk melihat regulasi yang telah disempurnakan tanpa perlu khawatir adanya regulasi yang tumpang tindih dan mengakibatkan kerugian kepada investor itu sendiri. Konsep ini menunjukkan ada politik hukum dari eksekutif untuk dilanjutkan melalui proses legislasi.

Pemerintah Saat ini sedang melakukan aktivitas untuk menentukan pola atau cara membentuk hukum dan memperbarui hukum melalui proses legislasi, sehingga terbentuk suatu legal policy yang bersifat sebagai hukum yang akan diberlakukan untuk penciptaan lapangan kerja. ${ }^{3}$ Ini berarti politik hukum dari Undang - Undang No. 11 Tahun 2020 Tentang Cipta Kerja adalah pembentukan hukum dengan menerapkan omnibus law dalam perumusan hukum untuk peningkatan investasi sehingga tercipta lapangan kerja.

Akan tetapi ada satu hal yang sangat penting dan menjadi permasalahan utama didalam penyusunan UU ini. Salah satu Permasalahan tersebut adalah adanya pemotongan pesangon kepada para buruh yang di putus hubungan kerjanya oleh perusahaan, Hilangnya cuti melahirkan dan lain sebagainya. Dari itu banyak para buruh dan masyarakat yang menolak adanya Undang - Undang No. 11 Tahun 2020 Tentang Cipta Kerja ini. Hal tersebut menunjukkan ada dinamika dalam pembentukan Undang - Undang No. 11 Tahun 2020 Tentang Cipta Kerja, baik secara formal maupun materiil. Atas dasar itu penulis mencoba menganalisis tentang Undang - Undang No. 11 Tahun 2020 Tentang Cipta Kerja.

Berdasarkan uraian singkat di atas, timbul permasalahan yaitu: (1) Perbandingan antara UU No. 13 Tahun 2003 Tentang Ketenagakerjaan dengan Undang - Undang No.

3 Rahmat Saputra. (2020). Kedaruratan Dalam Perspektif Hukum Responsif: Studi Kasus Pembatasan Sosial Berskala Besar di Indonesia. KRTHA BHAYANGKARA, 14(2). https://doi.org/10.31599/krtha.v14i2.523 
11 Tahun 2020 Tentang Cipta Kerja?; (2) Pasal apa saja yang menjadi Urgensi dalam Undang - Undang No. 11 Tahun 2020 Tentang Cipta Kerja?

\section{METODE PENELITIAN}

Metode yang digunakan dalam penelitian ini adalah dengan pendekatan yuridis normatif yaitu dengan melakukan penelitian berdasarkan pada bahan-bahan hukum / referensi dengan cara menelaah teori-teori dan konsep-konsep dari bahan-bahan hukum tersebut, yang berkaitan dengan asas-asas hukum peraturan perundang-undangan yang berhubungan dengan penulisan / penelitian ini.

\section{PEMBAHASAN}

Pada dasarnya Omnibus Law merupakan salah satu metode pembentukan undang-undang yang mengatur materi multisektor. Selain itu, UU ini juga mampu merevisi hingga mencabut ketentuan yang ada di dalam UU lain. Sejumlah negara sudah menerapkan omnibus law sebagai strategis untuk menyelesaikan persoalan regulasi yang berbelit dan tumpang tindih. Sebagai sebuah metode, pendekatan omnibus law berpeluang mengabaikan prinsip-prinsip penting dalam pembentukan undang-undang's.

Undang-Undang No. 11 Tahun 2020 Tentang Cipta Kerja menjadi “jagoan” dari Pemerintah, tercatat ada 79 Undang-Undang terdampak yang dikumpulkan menjadi satu undang-undang sehingga Undang - Undang No. 11 Tahun 2020 Tentang Cipta Kerja sering disebut sebagai UU “Sapu Jagat" karena begitu luas aturannya dalam Undang Undang No. 11 Tahun 2020 Tentang Cipta Kerja yang lintas sektor dan interdispliner. UU ini sifatnya merevisi (mengoreksi) pasal-pasal yang tidak sesuai dengan filosofi kemudahan berinvestasi dari Undang-Undang yang berserakan dalam sistem perundangundangan di Indonesia. Maka, pasal-pasal yang cenderung menghambat investasi akan dihilangkan.

Ada dua catatan apabila konsep Omnibus Law ini menjadi pilihan sebuah politik hukum bangsa Indonesia dalam upaya memberikan dasar hukum penciptaan lapangan pekerjaan melalui Undang - Undang No. 11 Tahun 2020 Tentang Cipta Kerja ini. Pertama, Ruh atau Jiwa sebuah Undang-Undang terletak dalam landasan filosofis yang termuat dalam konsiderans. Ruh Undang-Undang tersebut kemudian harus menjiwai dan mewarnai setiap pasal demi pasal. Landasan filosofis ini adalah asas materil yang harus ada dan menjadi syarat (conditio sine quo non) dalam setiap pembentukan undang-undang. 
Satjipto Rahardjo, berpendapat bahwa asas hukum adalah jantungnya peraturan hukum, karena asas hukum merupakan landasan yang paling luas bagi lahirnya suatu peraturan hukum. Asas hukum layak disebut sebagai alasan lahirnya peraturanhukum, atau merupakan ratio legis dari peraturan hukum. Dengan adanya asas hukum, maka hukum bukanlah sekedar kumpulan peraturan-peraturan, karena itu mengandung nilai-nilai dan tuntutan-tuntutan etis (Satjipto Rahardjo, 1986). Oleh karena itu, setiap undang-undang harus memiliki landasan filosofis sebagai asas materil yang jelas sesuai dengan karakter bangsa Indonesia.

Pada Undang - Undang No. 11 Tahun 2020 Tentang Cipta Kerja filosofinya adalah membuka dan mempermudah investasi ${ }^{4}$ sedangkan Undang-Undang Nomor 13 Tahun 2003 Tentang Ketenagakerjaan filosofinya adalah perlindungan tenaga kerja. Jika PasalPasal UU Ketenagakerjaan yang direvisi kemudian masuk dalam Undang - Undang No. 11 Tahun 2020 Tentang Cipta Kerja maka akan terjadi konflik filosofis yaitu antara filosofi kemudahan investasi visa-visa dengan filosofi perlindungan pekerja sehingga menyebabkan ketidakpastian hukum. Untuk menghindari ketidakpastian hukum, maka RUU Cipta Kerja harus mengandung 3 bentuk perlindungan hukum kepada para pekerja. yaitu: Perlindungan Ekonomis, Perlindungan Teknis dan Perlindungan Sosial.

Kedua, Kesiapan bangsa Indonesia untuk menerapkan konsep Omnibus Law. Konsep Omnibus Law ini bukanlah barang baru. Jauh sebelumnya Amerika Serikat, Kanada, Australia, bahkan Vietnam sudah pernah melakukannya terlebih dahulu. Penerapan Omnibus Law atau Omnibus Bill membutuhkan tenaga SDM yang besar, banyak dan profesional, koordinasi antara lembaga negara harus terjalin baik, keterlibatan pakar dari berbagai disiplin ilmu dan terlibatnya stakeholder.

Didalam UU 13 Tahun 2003 tentang ketenagakerjaan menjelaskan bahwa pemutusan hubungan kerja adalah pemutusan hubungan kerja karena satu hal tertentu yang mengakibatkan berakhirnya hak dan kewajiban antara pekerja atau buruh dan pengusaha. Hubungan kerja antara perusahaan atau pengusaha dengan pekerja, secara yuridis, penerima kerja atau pekerja memiliki prinsip kebebasan karena negara kita tidak menghendaki adanya praktik perbudakan yang dilakukan oleh siapapun. ${ }^{5}$

Konsep dasar pemberian pesangon ini didasarkan pada adanya sebuah pemutusan hubungan kerja yang mewajibkan perusahaan untuk memberikan sebuah apresiasi kepada

${ }^{4}$ Adhi Setyo Prabowo, dkk. ” Politik Hukum Omnibus Law di Indonesia", Jurnal Pamator, Vol.13, No.1, 2020, Hal. 2

5 Wisnu Aryo, "Problematika Pembentukan Run cipta kerja dengan konsep omnibus law" Jurnal Panorama Hukum, Vol.1 No.5 2020. Hal.7 
pekerja yang telah memberikan kontribusi terhadap perusahaan.. Sehingga kesan daripada memperbudak pekerja oleh perusahaan dihilangkan agar tidak ada pihak yang merasa dirugikan. Karna dalam hal PHK dapat terjadi karena Perusahaan Pailit sehingga mengurangi kuota pekerjanya. Menurut Keputusan Menteri Tenaga Kerja Nomor 150 Tahun 2000 mendefinisikan pesangon merupakan sebuah pembayaran uang dari pemberi kerja (Pengusaha) kepada pekerja sebagai akibat dari adanya pemutusan hubungan kerja ${ }^{6}$ Pada konteks Undang - Undang No. 11 Tahun 2020 Tentang Cipta Kerja ini problematika yang ada didalamnya memang begitu kompleks. Ini dikarenakan Undang Undang No. 11 Tahun 2020 Tentang Cipta Kerja berusaha untuk menghapus dan mengubah beberapa regulasi seperti Undang-Undang nomor 13 tahun 2003 tentang ketenagakerjaan, Undang-Undang nomor 40 tahun 2004 tentang sistem jaminan sosial dan Undang-Undang nomor 24 tahun 2011 tentang badan penyelenggaran jaminan sosial menjadi satu bentuk peraturan yang selaras dengan visi penciptaan lapangan kerja yang masif hingga beberapa tahun ke depan.

Pembahasan klaster ketenagakerjaan ini menyoroti permasalahan yang terdapat pada pasal 89 yang mengatur mengenai pemberian uang pesangon dan uang penghargaan bagi pekerja yang di PHK. Pada pasal 89 ayat 1 ketentuan ini mengubah ketentuan pasal 156 ayat 1 Undang-Undang Nomor 13 tahun 2003 tentang ketenagakerjaan yang berbunyi: "Dalam hal terjadi pemutusan bubungan kerja, pengusaha diwajibkan membayar uang pesangon dan atau uang penghargaan masa kerja dan uang penggantian hak yang seharusnya diterima". Kemudian redaksi ini diganti menjadi: "Dalam hal terjadi pemutusan bubungan kerja, pengusaha wajib membayar uang pesangon dan/ atau uang penghargaan masa kerja".7

Bila di telaah dirubahnya ketentuan ini merupakan penurunan kesejahteraan buruh yang menghilangkan ketentuan uang penggantian yang seharusnya diterima oleh pekerja. Kemudian pada ayat 3 pasal 89 Undang - Undang No. 11 Tahun 2020 Tentang Cipta Kerja juga merubah ketentuan di dalam pasal 156 Undang-Undang Nomor 13 tahun 2003 tentang ketenagakerjaan yang lebih spesifik perubahan tersebut ada pada huruf $g$ dan yang ada pada Undang-Undang Ketenagakerjaan dihapuskan pada Undang - Undang No. 11 Tahun 2020 Tentang Cipta kerja. Perubahan yang terjadi ini dari segi tujuan adanya hukum tidaklah memberikan sebuah kemanfaatan atau kebahagiaan bagi para pekerja.

Namun disisi lain adanya UU ini memberikan sebuah keadilan antara kaum pekerja dengan pelaku usaha. Ini dikarenakan penghapusan huruf $g$ dan h ayat 3 pasal 156

\footnotetext{
${ }^{6}$ Keputusan Menteri Tenaga Kerja Nomor 150 Tahun 2000 Pasal 1 ayat (6)

${ }^{7}$ Ibid, Hal. 9
} 
Undang-Undang Nomor 13 tahun 2003 dan dihapusnya ketentuan uang penggantian yang seharusnya diterima tidak serta merta merugikan kaum buruh secara signifikan namun pemerintah mencoba memberikan sebuah stimulus agar investor mau menanamkan modalnya dengan sedikit memberikan kelonggaran terhadap perusahaan untuk meniadakan beberapa kewajiban yang telah tertulis didalam pasal 89 Undang - Undang No. 11 Tahun 2020 Tentang Cipta Kerja. Sebenarnya langkah tersebut merupakan bentuk upaya pemerintah dalam membangun perekonomian di Indonesia sehingga mewujudkan kesejahteraan sosial, dan yang selalu menjadi permasalahan adalah para pekerja melalui serikat buruh sering lebih banyak menuntut haknya dengan tidak diimbangi oleh etos kerja yang baik, sehingga sudah menimbulkan keengganan dari inverstor atau pengusaha untuk membuka sektoral perushaannya di Indonesia. ${ }^{8}$

Meskipun Undang - Undang No. 11 Tahun 2020 Tentang Cipta Kerja Pemerintah telah mencoba memberikan garansi lain untuk kesejahteraan para pekerja ketika mengalami PHK yakni dengan adanya jaminan kehilangan pekerjaan pada pasal 90 Undang - Undang No. 11 Tahun 2020 Tentang Cipta Kerja yang merubah ketentuan pasal 18 Undang-Undang Nomor 40 tahun 2004 tentang sistem jaminan sosial nasional dan ketentuan pasal 6 Undang-Undang Nomor 24 tahun 2011 tentang badan penyelenggara jaminan sosial. Dimana hal ini merupakan upaya tanggung jawab dengan menghilangkan hak-hak dari para pekerja sehingga jelas bahwa seharusnya adanya Undang - Undang No. 11 Tahun 2020 Tentang Cipta Kerja pada Klaster Ketenagakerjaan ini mampu memberikan dampak positif kepada negara dengan tidak menghilangkan nilai keadilan daripada adanya hukum tersebut yang diperuntukkan bagi masyarakat. ${ }^{9}$

Ironinya, Undang - Undang No. 11 Tahun 2020 Tentang Cipta Kerja belum memperhatikan beberapa aspek lain yang berkaitan dengan hak bagi pekerja yang mengalami pemutusan hubungan kerja. Karena mengingat dengan dihapuskannya beberapa ketentuan pesangon pada Undang - Undang No. 11 Tahun 2020 Tentang Cipta Kerja, akan mendeskriditkan posisi tenaga kerja. Manakala melihat dari teori hukum, substansi pada pasal 89 angka 45 Undang - Undang No. 11 Tahun 2020 Tentang Cipta Kerja tidak memberikan sisi kemanfaatan kepada para buruh sehingga menyebabkan banyak para buruh menolak adanya Undang - Undang No. 11 Tahun 2020 Tentang Cipta Kerja tersebut.

\footnotetext{
${ }^{8}$ Ibid, hal 10

9 Wisnu Aryo, "Problematika Pembentukan RUU cipta kerja dengan konsep omnibus law" Opcit,
} Hal. 10 
Karena hukum seharusnya dapat memberikan rasa manfaat kepada masyarakat pada umumnya. Hukum hadir di masyarakat harus mampu memberikan sebuah manfaat atau kegunaan. Jangan sampai ketika hukum dilaksanakan malah menimbulkan sebuah keresahan di dalam masyarakat itu sendiri. ${ }^{10}$

Hal ini menjadi permasalahan yang harus dikaji dan diselesaikan oleh pemerintah, karena jika semakin melemahkan posisi tenaga kerja dimata perusahaan maka akan lahirlah eksploitasi tenaga kerja yang dilakukan oleh perusahaan. ${ }^{11}$

\section{KESIMPULAN}

Secara garis besar proses pembentukan perundang-undangan dengan konsep Omnibus Law ini tidak diatur secara jelas didalam Undang-Undang nomor 12 tahun 2011 tentang pembentukan perundang-undangan. Ini dikarenakan Omnibus Law adalah sebuah konsep berpikir yang memiliki karakteristik mampu mengubah dan menghapus beberapa regulasi menjadi satu peraturan yang mampu mencakup seluruh aspek. Meskipun konsep seperti ini masih baru, seharusnya dalam regulasi pembentukan undang-undang sudah diatur agar pesan baik yang terdapat pada konsep tersebut mampu dilaksanakan dengan baik sehingga tidak menimbulkan permasalahan baru di masyarakat.

Undang - Undang No. 11 Tahun 2020 Tentang Cipta Kerja ini masih memiliki banyak kelemahan yang berpotensi membuat masalah baru di kalangan masyarakat. Masalah ini ada pada perubahan ketentuan pemberian pesangon pada pasal 89 angka 45 yang merubah ketentuan didalam Undang-Undang Nomor 13 tahun 2013 tentang ketenagakerjaan. Sampai hari ini masih banyak kasus perusahaan yang melanggar ketentuan pemberian pesangon kepada para tenaga kerja. Secara yuridis perubahan tersebut semakin mempersempit ruang gerak para tenaga kerja untuk memperjuangkan hak-hakya dan memberikan dominasi pengusaha untuk melakukan eksploitasi terhadap tenaga kerja.

Undang - Undang No. 11 Tahun 2020 Tentang Cipta Kerja ini merupakan regulasi yang digunakan oleh pemerintah untuk membangun perekonomian Indonesia menjadi lebih baik. Namun, seharusnya secara substansi kepentingan dari para tenaga kerja di Indonesia haruslah menjadi salh satu poros yang dipertimbangkankarena tena kerja adalah asset perusahaan. Regulasi dalam Undang - Undang No. 11 Tahun 2020 Tentang Cipta Kerja haruslah seimbang dari segi investor (pengusaha) sehingga mampu menarik minat

\footnotetext{
10 Peter Mahmud Marzuki, Pengantar Ilmu Hukum, Kencana: Jakarta, 2017, Hal.97

${ }^{11}$ Wisnu Aryo, "Problematika Pembentukan Ruu cipta kerja dengan konsep omnibus law" Opcit,
} Hal. 11 
investor untuk menanamkan modalnya di Indonesia dengan tanpa mengorbankan kepentingan masyarakat dalam hal ini tenaga kerja.

\section{Saran}

Dalam terwujudnya keadilan dan kesejahteraan yang Optimal dari berlakunya Undang Undang No. 11 Tahun 2020 Tentang Cipta Kerja ini maka juga dibutuhkan peran yang besar dari para pengusaha atau investor yang ada membangun dan mempekerjakan para buruh untuk menjaga stabilitas dan ikut lebih mensejahterakan pekerjanya, karna itu menjadi faktor dari optimalisasi dalam bekerja dan bersentuhan langsung dengan hasil produksi yang dihasilkan bila persentase nya banyak yang Not Good dalam Quaity Control maka akan merogoh Cost lebih dari perusahaan.

Agar Pemerintah dan Legislatif dalam menyusun suatu perundang - undangan dapat lebih banyak lagi melibatkan institusi, para akademisi, dan peninjauan secara empiris sehigga produk hukum yang diciptakan dapat melindungi segenap bangsa Indonesia.

\section{DAFTAR PUSTAKA}

\section{Buku}

Asyhadie, Zaeni. 2013. "Aspek-Aspek Hukum Jaminan Sosial Tenaga Kerja Di Indoensia". Jakarta. RajaGrafindo Persada.

Marzuki, Peter Mahmud. 2017. “Pengantar Ilmu Hukum” Jakarta. Kencana

Taufiqurrohman Syahuri, 2011, Tafsir Konstitusi Berbagai Aspek Hukum, Jakarta: Kencana Prenada Media Group.

\section{Perundang-undangan}

Undang - Undang No. 13 Tahun 2003 Tentang Ketenagakerjaan

Undang - Undang No. 11 Tahun 2020 Tentang Cipta Kerja

Peratuan Pemerintah No. 35 Tahun 2021 Tentang Perjanjian Kerja Waktu Tertentu, Alih Daya, Waktu Kerja dan Waktu Istirahat, dan Pemutusan Hubungan Kerja. 


\section{Jurnal}

Aryo, Wisnu. 2020. "Problematika Pembentukan RUU cipta kerja dengan konsep omnibus law" Jurnal Panorama Hukum, Vol.1 No.5

Asshiddiqie, J., \& Marwan, A. . (2020). Proklamasi Menurut Mohammad Yamin: Berdaulat Dan Berkonstitusi. Jurnal Hukum Sasana, 5(1). https://doi.org/10.31599/sasana.v5i1.89

Ima Mayasari, 2020, Kebijakan Reformasi Regulasi Melalui Implementasi Omnibus Law Di Indonesia, Jurnal Rechvinding Vol 9 No 1.

Prabowo, Adhi Setyo Dkk., 2020, "Politik Hukum Omnibus Law di Indonesia”, Jurnal Pamator, Vol.13, No.1.

Saputra. Rahmat (2020). Kedaruratan Dalam Perspektif Hukum Responsif: Studi Kasus Pembatasan Sosial Berskala Besar di Indonesia. KRTHA BHAYANGKARA, 14(2). https://doi.org/10.31599/krtha.v14i2.523

Suwandi Arham, 2020, Omnibus Law Dalam Perspektif Hukum Indonesia, Vol 7, No. 2.

Tohadi. 2020 "Kajian Kritis atas kewenangan Presiden untuk membatalkan Peraturan daerah dalam Omnibuslaw", Jurnal Rechts Vinding, Vol.9 No.1

Umarama. Tarsan. (2021). Constitutional Question di Mahkamah Konstitusi Sebagai Pelindung Hak Konstitusional Warga Negara Perspektif Siyasah Qadlaiyyah. KRTHA BHAY ANGKARA, 15(1). https://doi.org/10.31599/krtha.v15i1.511 